\title{
Organic synthetic anionic surfactants as persistent organic pollutants of water ecosystems
}

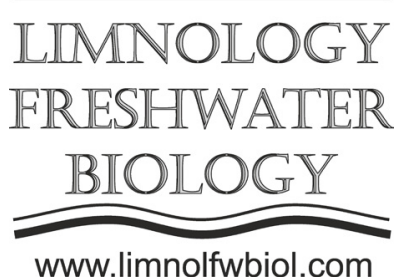

\begin{abstract}
Nikonova A.A.
Limnological Institute of Siberian Branch of Russian Academy of Sciences, Ulan-Batorskaya St. 3, 664033, Irkutsk, Russia

ABSTRACT. Organic synthetic anionic surfactants are widely spread environmental pollutants. Most of them are high-toxic xenobiotics in environment. They are accumulated in aquatic habitats, transported through the food webs and slowly degrade. Despite the problem importance and higher concentrations of these toxicants in environment compared to well-known persistent organic pollutants such as PCDD, PCDF, PCB, PAH, and others at present surfactants determination is of too low interest. The report presents basic properties of these substances, ways of their incoming into the environment, distribution, behavior in ecosystems, including Lake Baikal, toxicity, effect on water organisms, and other common aspects.
\end{abstract}

Keywords: synthetic anionic surfactants, persistent organic pollutants

Synthetic anionic surfactants are organic substances. Surfactant molecules consist of polar tail and nonpolar head. Because of various interactions such as head-head, head-tail, and tail-tail, surfactants decrease the surface tension at the interphase boundary that produces different aggregates, such mono- and multylayers (films), direct and opposite bubbles, micelles, microemulsions, etc. (Ceraulo et al., 2011). There are three types of synthetic surfactants: anionic, cationic, and nonionogenic. ASAS are mostly toxic due to their high solubility in water, bioaccumulation and low biodegradation (Denyushkin, 2017).

Among the most wide-spread surfactants there are salts of alkylsulfuric acids such as alkylsulphates of sodium, calcium, ammonium, and salts of alkylaromatic sulfonic acids (sulfonates), particularly, isomers of sodium alkylbenzenesulfonate (Gladilovich et al., 1996). The last ones are produced in the world since 1964 (Environmental Risk Assessment, 2013). Thus, in 1974, 0.015 million tons of sulphanole were produced, in $1986-0.5$, in $1998-1.5$, in $2002-3$, and in 2016 -11 million tons already.

Effect of anionic surfactants such as sodium alkylbenzenesulfonate and its isomers (LASs) on the environment depends on commercial product composition. Isomer toxicity is higher for isomers with long alkyl chain, and in the case of the phenyl group conjugated to outer carbonic atoms of alkyl chain (see Fig. 1A). Properties of most toxic isomers are explained of their absorption on suspension and organism surfaces, bioavailability, high ability to bioaccumulation and low biodegradation (Belanger et al., 2002).
In water medium, surfactant molecules are aggregated. The hydrophilic heads are in the water and the hydrophobic tails are out of the water medium. They form films at the water surface which separate water and air media. This prohibits gas exchange between them that can result in organism mortality and suffocation. Surfactants wash out lipids from mammal skin, bird feather, result in animal mortality because of supercooling, destroy fish body mucous, cause fungal and parasitic invasion, breath disfunction, and stimulate the growth of water plants etc. After plants die off, their rot flax to water that results to oxygen concentration decrease. Many surfactants destroy cell plant membrans (Ostroumov, 2001; Belanger et al., 2002), cause degradation of polyunsaturated fatty acids by active oxygen, increase concentration of soluble carbohydrates, proteins, hydrogen peroxide and malonic aldehyde which able to form DNA mutagenic adducts (Marnett, 1999; Zhou et al., 2018).

Persistent anionic surfactant determination in the ecological monitoring of Lake Baikal taking into account its status as a region of world natural heritage of the UNESCO, sources of incoming of these toxicants into the lake (see Figure, b), and their high toxicity of these xenobiotics for the unique Lake Baikal ecosystem needs using of high precision equipment and analytical techniques.

\section{Acknowledgements}

The author thanks the Head of the Laboratory of Chromatography LIN SB RAS PhD (Chemistry) Docent 

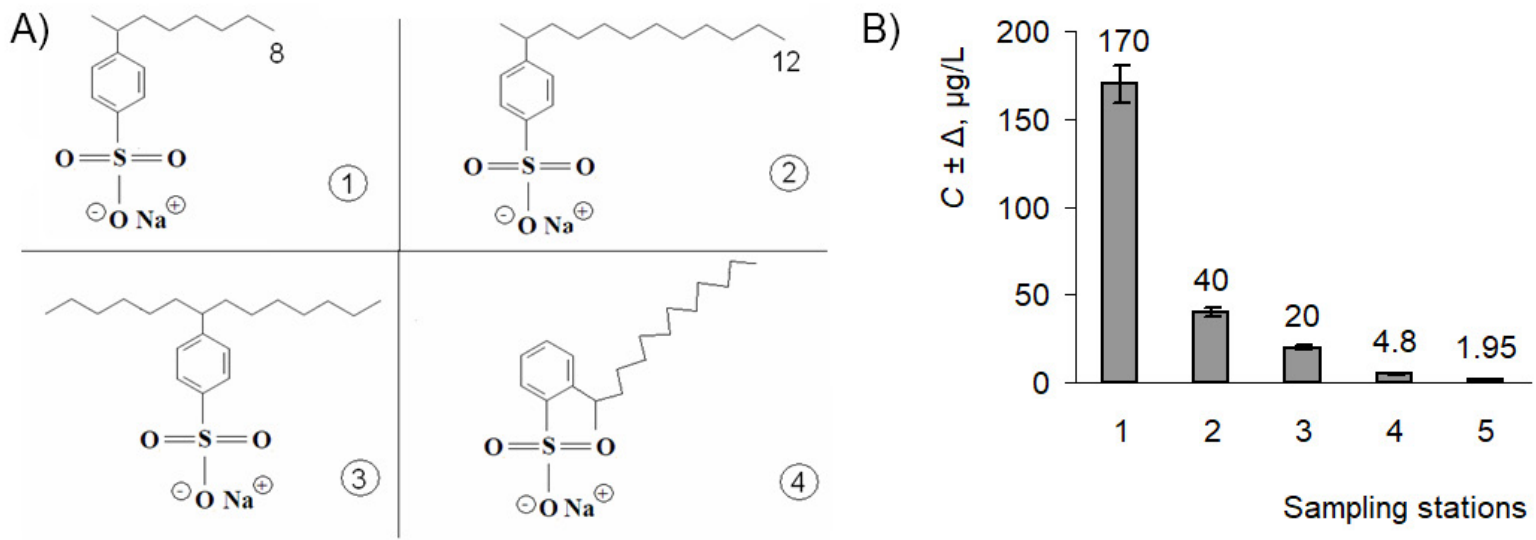

Fig.1. A. Surfactant structure examples. Toxicity of the substance No. 2 is higher than that of substance No. 1 because of chain length. Toxicity of the substance No. 3 is higher than that of substance No. 2 because of phenyl group. Toxicity of the substance No. 4 is higher than that of substance No. 3 because of phenyl orthoposition. B. Persistent anionic surfactant concentrations in sewage water of Severobaikalsk (Republic of Buryatia) (1); in surface water in mouth of Tyya river (2) which is Lake Bailal tributary; in surface water near the Village of Zarechnyi (North Baikal) (3); surface water near Cape Ludar (North Baikal) (4); pelagic deep water (400 m) opposite Cape Elokhin (North Baikal). Water samples from Lake Baikal were taken in September 2019.

Gorshkov A.G., the academic of Russian Academy of Sciences Doctor of Sciences (Chemistry) leading scientific worker Prof. M.A. Grachev, the Director of LIN SB RAS Doctor of sciences (Geology and Mineralogy) A.P. Fedotov, the Doctor of Sciences (Geography) Senior Researchworker I.B. Mizandrontsev for helpful advises, Researchworkers of the Laboratory of Water Microbiology LIN SB RAS PhDs (Biology) I.V. Tikhonova and E.T. Sorokovikova for financial support (RFBR 18-54-05005), Researchworker of the Laboratory of Hydrochemistry and Chemistry of Atmosphere LIN SB RAS PhD (Geography) M.V. Sakirko and my parents.

\section{References}

Belanger S.E., Bowling J.W., Lee D.M. et al. 2002. Integration of aquatic fate and ecological responses to linear alkyl benzene sulfonate (LAS) in model stream ecosystems. Ecotoxicology and Environmental Safety 52: 150-171. DOI: 10.1006/eesa.2002.2179

Ceraulo L., Giorgi G., Liverdi V.T. et al. 2011. Mass spectrometry of surfactant aggregates. Review. European Journal of Mass Spectrometry 17: 525-541. DOI: 10.1255/ ejms.1158
Denyushkin A.V. 2017. Methods for determination of synthetic anionic surfactant substances in wastewater. In: International Scientific and Practical Conference "Unity and Identity of Science: Problems and Findings", p. 231. (in Russian)

Environmental Risk Assessment. LAS. Linear Alkylbenzene Sulphonate (CAS No. 68411-30-3). 2013. Revised Environmental Aspect of the HERA Report. February 2013.

Gladilovich D.B., Volosnikova E.A., Ilyukhin A.V. et al. 1996. Techniques for anionic surfactants determination by fluorimetry in samples of fresh water, surface water and underground water. MUK 4.1.070-96. St.-Petersburg, 1996. (in Russian)

Marnett L.J. 1999. Lipid peroxidation - DNA damage by malondialdehyde. Mutation Research 424(1-2): 83-95. DOI: 10.1016/S0027-5107(99)00010-X

Ostroumov S.A. 2001. Biologicheskiye effekty pri vozdeystvii poverkhnostno-aktivnykh veshchestv na organizmy [Biological effects under the action of surfactant substances on organisms]. Moscow: MAKS-Press. (in Russian)

Zhou J., Wu Z., Yu D. et al. 2018. Toxicity of linear alkylbenzene sulfonate to aquatic plant Potamogeton perfoliatus L. Environmental Science and Pollution Research 25(32): 32303-32311. DOI: 10.1007/s11356-018-3204-7 